\title{
Hydrochemistry of surface water and groundwater from a fractured carbonate aquifer in the Helwan area, Egypt
}

\author{
Fathy A AbDalla ${ }^{1, *}$ and Traugott Scheytr $^{2, * *}$ \\ ${ }^{1}$ Geology Department, Faculty of Science, South Valley University, Qena, Egypt. \\ ${ }^{2}$ Department of Applied Geosciences, Technische Universität Berlin, Berlin, Germany. \\ ${ }^{*}$ Corresponding author.e-mail: fathyhyd@yahoo.com \\ ${ }^{* *}$ e-mail: traugott.scheytt@tu-berlin.de
}

\begin{abstract}
Groundwater is an important water resource in the Helwan area, not only for drinking and agricultural purposes, but also because several famous mineral springs have their origin in the fractured carbonate aquifer of the region. The area is heavily populated with a high density of industrial activities which may pose a risk for groundwater and surface water resources. The groundwater and surface water quality was investigated as a basis for more future investigations. The results revealed highly variable water hydrochemistry. High values of chloride, sulphate, hardness and significant mineralization were detected under the industrial and high-density urban areas. High nitrate contents in the groundwater recorded in the southern part of the study area are probably due to irrigation and sewage infiltrations from the sewage treatment station. The presence of shale and marl intercalation within the fissured and cavernous limestone aquifer promotes the exchange reactions and dissolution processes. The groundwater type is sodium, sulphate, chloride reflecting more mineralized than surface water. The results also showed that water in the study area (except the Nile water) is unsuitable for drinking purposes, but it can be used for irrigation and industrial purposes with some restrictions.
\end{abstract}

\section{Introduction}

The water demand in Egypt is met mostly by surface water supplies from the Nile River. Faced with a burgeoning population growth, groundwater will be an important source of future water supply and plays a crucial role in any kind of development. Groundwater contamination decreases the amount of available groundwater, especially in the presence of fractures and macro-pores, which can rapidly distribute solutes over vast areas. In the case of fractured aquifers, advective-dispersive transport is combined with matrix diffusion (Bäumle et al 2000; Bäumle 2003; Witthüser et al 2003; Bodin et al 2003a, 2003b; Abdalla 2004).
Helwan springs are characterized by their high contents of $\mathrm{H}_{2} \mathrm{~S}$, and an unpalatable saline taste imparted by the high mineral content. Colour intensity and turbidity are also relatively high. The circulation of spring water through limestone, the biological activity and the presence of $\mathrm{CO}_{2}$ in the soil are all the reasons responsible for the dissolution of carbonate rocks and generation of some karst feature under the Helwan area (Said 1954).

The total discharge of Helwan springs reaches more than $0.11 \mathrm{~m}^{3} / \mathrm{s}$. Most of this water is currently wasted by discharging it to the sanitary system, especially for the Ezbt El-Bharya spring. The measured water temperature ranges from $23^{\circ}-$ $32^{\circ} \mathrm{C}$. Applying geothermometery (e.g., El Ramly

Keywords. Carbonate aquifer; hydrochemistry; Nile; anthropogenic activities; alluvial plain; Egypt. 
1969; Reed and Spycher 2000), the reservoir temperature is expected to fall between $80^{\circ} \mathrm{C}$ and $160^{\circ} \mathrm{C}$.

The specific objectives of the work were to investigate the hydrochemical characteristics of the groundwater from the fractured carbonate aquifer and surface water in the Helwan area and to discuss the possibility of groundwater use for drinking, agricultural and industrial purposes. This study aims at providing a basis for an interpretation of the quality of water resources in the Helwan area, trying to distinguish the different effects on groundwater and surface water quality.

\section{Study area}

The study area is a part of Greater Cairo, east of the River Nile directly about $20 \mathrm{~km}$ south of Cairo and $40 \mathrm{~m}$ above sea level. It extends between longitude $\left(31^{\circ} 15^{\prime} 54^{\prime \prime}-31^{\circ} 23^{\prime} 7^{\prime \prime} \mathrm{E}\right)$ and latitude $\left(29^{\circ}\right.$ $43^{\prime} 21^{\prime \prime} \mathrm{N}-29^{\circ} 51^{\prime} 52^{\prime \prime} \mathrm{E}$ ) (figure 1).
The area is characterized by an arid climate with warm winter and hot summer with average daily temperature ranges from $14^{\circ}$ to $31^{\circ} \mathrm{C}$. The longterm average rainfall is about $25.7 \mathrm{~mm} /$ year, evapotranspiration rate ranges from about $256 \mathrm{~mm} /$ year in winter to about $5746 \mathrm{~mm} /$ year in summer and relative humidity from 50 to $70 \%$ (Elminir et al 2005). Other sources of water for evapotranspiration processes are the surface water system in the study area which includes the Nile, canals and drains as well as many ponds. During the period 1955 to 1975 , Helwan and its nearby surroundings were considered as one of the most important industrial district in Egypt with all the negative side effects involved especially to the environment. This is due to the presence of some large national industrial facilities such as iron and steel, cement, car manufacturing, coal industry as well as red brick factories. Industries consume significant amounts of water and return in many cases highly polluted wastewater sometime directly to the environment. Hence, these activities are considered

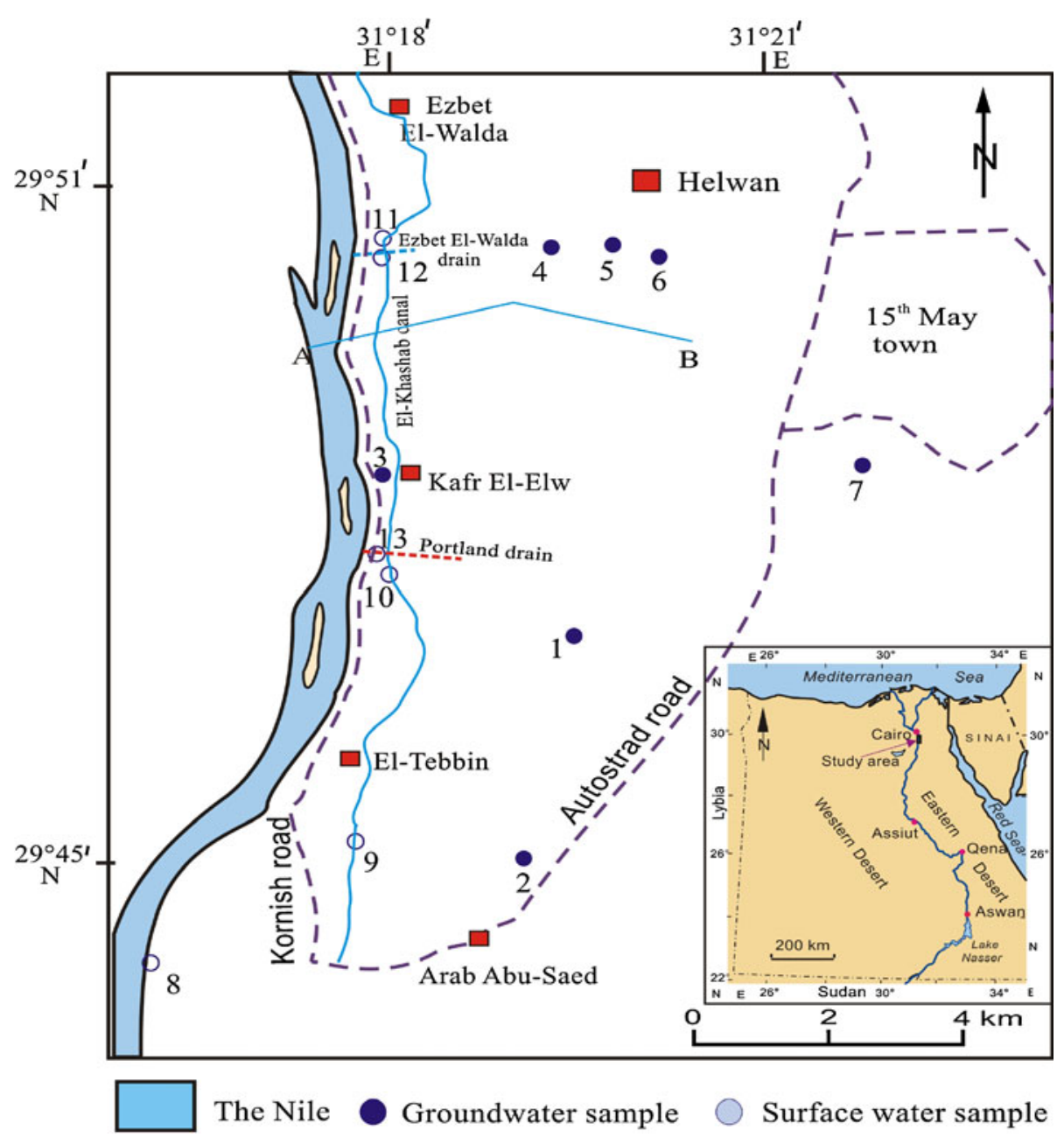

Figure 1. Location map showing the sampling points (numbers 1 to 13 ) and trace of hydrogeological cross section AB in the study area. 
as an important source of water pollution (Fayez and Shahin 2007; Han 2007; Mahmoodabady et al 2010). Moreover, the area has some tourist activities due to the presence of the above-mentioned mineral and sulphurous springs. The area includes a few small villages (Ezab), for example, Ezbt ElWalda, Ezbt El-Bharya and El-Qeblya, Arab AbuSaed and others which are connected to the old and deteriorated sewage network. Some of the scattered communities and houses are not connected to the public sewage network. They dispose domestic waste either in private septic tanks (latrines) or directly to the El-Khashab canal. The southern border of the study area is an agricultural area. This area might exhibit some inputs from agricultural activities (El-Sayed et al 2004; Taha et al 2004; Tawfik 2008).

\subsection{Geological setting}

Helwan area is characterized by a low relief and gentle slope from east to west. The surface of the floodplain that occupies the banks of the River Nile consists of the fertile top clay-silt layer underlain by sand and gravel forming the alluvial aquifer. The floodplain is formed by a tectonic depression, and probably bounded by faults. Cretaceous and Tertiary rocks are exposed at the border of the floodplain. From the geomorphologic point of view, the area is discriminated into three geomorphologic units (figure 2): the structural plateau which consists mainly of limestone and is dissected by a number of faults, the piedmont plain and the Nile flood plain which is formed by a tectonic depression.

Rocks exposed in the Greater Cairo area include rocks of Quaternary, Tertiary and Late Cretaceous with a maximum thickness about $900 \mathrm{~m}$ (table 1). Eocene rocks constitute the most common outcrops and mainly are limestone, marls and dolomites (Awad and Abdel-Baki 1993).

According to Aboushook and Sherif (2000) and Said (1962), Maadi Formation (Middle Eocene age) is made up of a series of brownish beds of fissured limestone, marl and shale (figure 3). It includes the following units from top to bottom: the yellowishwhite dolomitic limestone becoming sandy towards the base with traces of gypsum pockets; the alternating yellowish sandy and greyish shale beds with

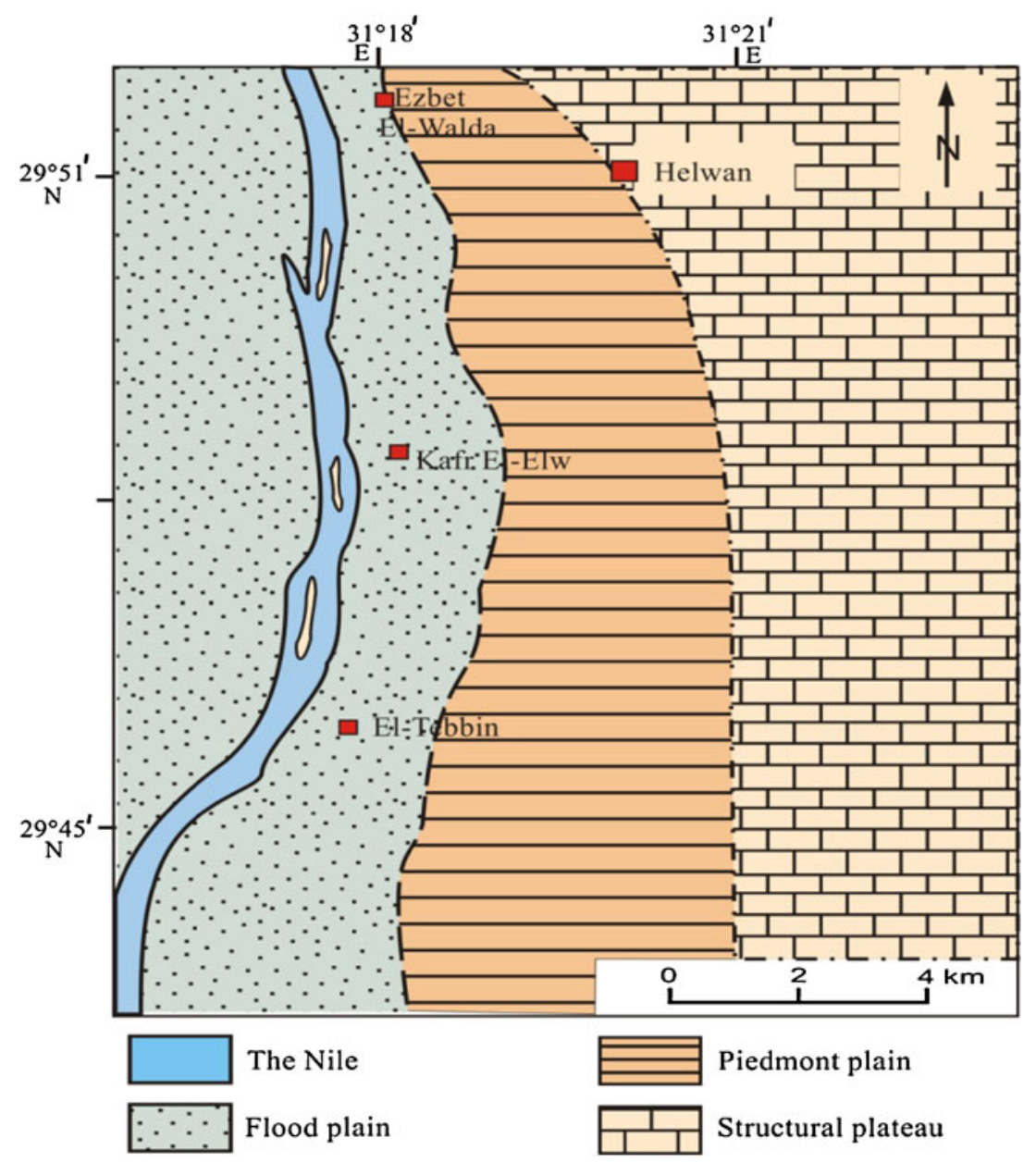

Figure 2. Main geomorphologic features in the study area. 
Table 1. Exposed geological units in the Greater Cairo area (modified from Awad and Abdel-Baki 1993).

\begin{tabular}{|c|c|c|c|}
\hline Age & Lithology & $\begin{array}{l}\text { Thickness } \\
\qquad(\mathrm{m})\end{array}$ & $\begin{array}{l}\text { Average hydraulic } \\
\text { conductivity }(\mathrm{m} / \mathrm{s})\end{array}$ \\
\hline \multicolumn{4}{|l|}{ Quaternary } \\
\hline Holocene & Silt, sandy clay, eolian sand & 15 & $2.8 \times 10^{-7}$ \\
\hline Pleistocene & Coarse sand and gravel with clay lenses & 70 & $9.3 \times 10^{-4}$ \\
\hline Pliocene & Sandy limestone, sandy marl, marly limestone & 42 & - \\
\hline Miocene & Sand, calcareous sandstone, gravel, limestone and shale & 45 & - \\
\hline \multicolumn{4}{|l|}{ Tertiary } \\
\hline Oligocene & Red sand and gravel with interbeds of clay and basalt & 160 & - \\
\hline Eocene & Greyish-white limestone & 200 & $1.1 \times 10^{-3}$ \\
\hline \multicolumn{4}{|l|}{ Cretaceous } \\
\hline Upper Cretaceous & $\begin{array}{l}\text { Limestone, chalk, marl, dolomite with some intercalations } \\
\text { of shale and sandstone }\end{array}$ & 400 & - \\
\hline
\end{tabular}

minor intercalation of marls and salts; the fissured and cavernous yellowish brown limestone with some marl and gypsum pockets and the alternating yellowish sandy and greyish shale beds with minor intercalation of marls and salts. It is characterized by the presence of the well defined fissures, caverns

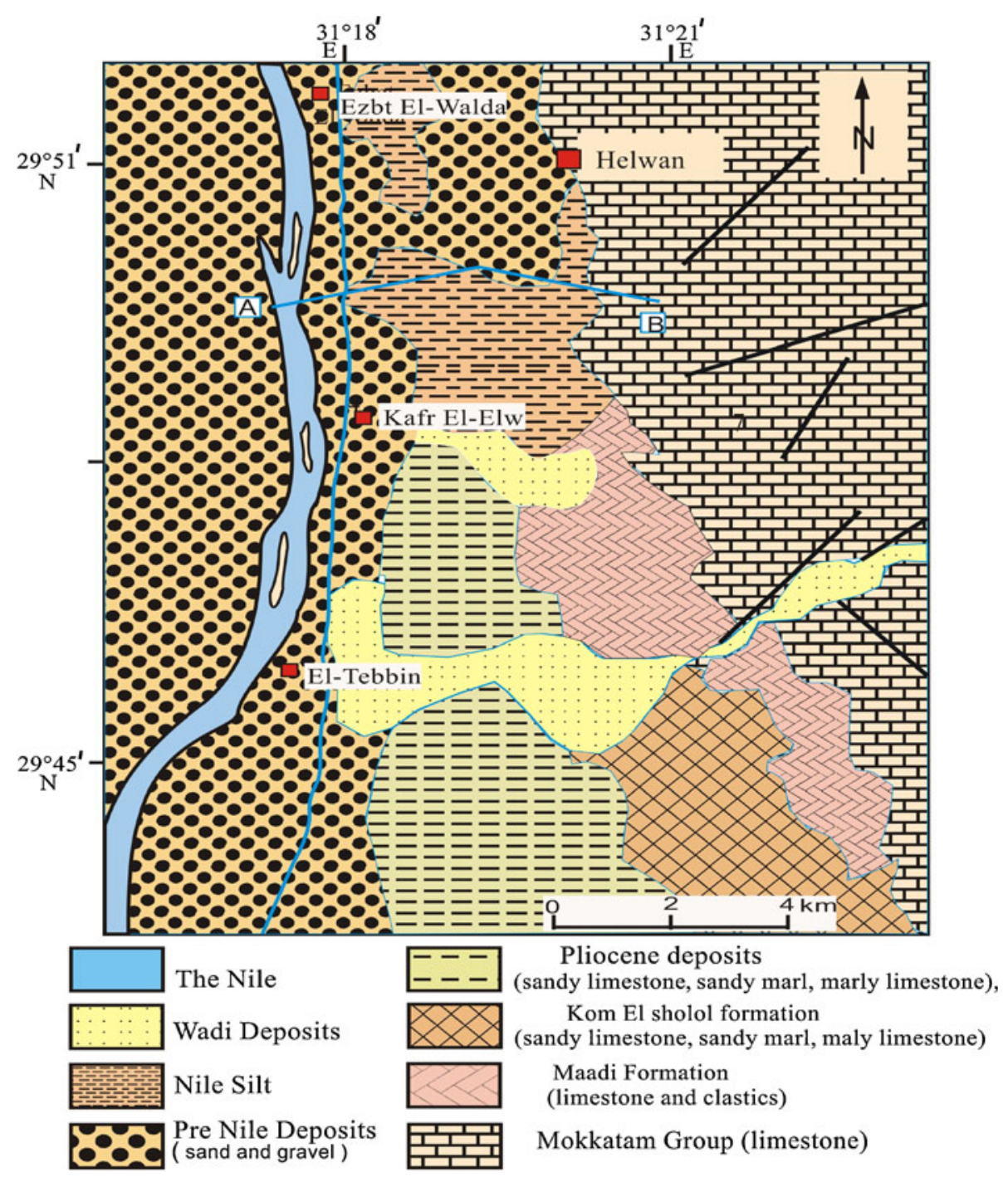

Figure 3. Geological map of the study area (CONOCO 1989). 
and joints which have east-west and northwestsoutheast directions. The joints have nearly a vertical dip angle and are filled with silty clayey materials (Abdeltawab 2008). The underlying Mokattam Formation which belongs to the Middle and Upper Eocene is a succession of sedimentary carbonates and less abundant argillaceous rocks. It consists of four units from top to bottom: the upper carbonate unit, which is mostly formed of jointed sandy dolomitic limestone; the upper clastic unit, which is partly dolomitized marl with ferruginous and calcareous patches; the lower carbonate unit, which is an interbedded unit of sandy dolomitic limestone and gypsiferous marly sands and the lower clastic unit, which consists mainly of shale over sandy marly limestones interbedded with shale.

Structurally, the study area was affected by three sets of faulting systems striking mainly in NW$\mathrm{SE}, \mathrm{E}-\mathrm{W}$ and NE-SW directions. All of them are normal faults, with dip ranges from $17^{\circ}$ to $40^{\circ}$, where the beds are locally dragged. In addition to faults, at least two sets of joints dissect the area. These joints trend in E-W and NW-SE directions (Moustafa et al 1985). Faulting is the dominating structural element and is mainly vertical and facilitates both the downward passage of water and upflow from deep aquifers (Farag and Ismail 1955; Elawadi et al 2006; Sultan et al 2008) the following.

The tectonic evolution of Egypt is complicated where all the tectonic trends are inherited from Precambrian tectonic discontinuities and had been reactivated several times during the Phanerozoic (Akawy 2009). The low angle of the normal faults $\left(17^{\circ}\right.$ to $\left.40^{\circ}\right)$ resulted from reactivation of the older tectonic discontinuities on the one hand, and the tilting of the fault blocks by later movements on the other hand. This was evidenced by the analysis of the paleostresses that indicated a slow change in the stress direction of the faults. In general, the stress regime analysis in some parts of Egypt showed a tendency to change from compressive (horizontal stress) to extensional (vertical stress) regime which resulted in low angle faults and tilting of older fault planes (Akawy and Zaky 2008; Akawy 2009).

\subsection{Hydrogeological setting}

The surface water system in the study area includes the Nile River, El-Khashab canal (mostly covered), Ezbt El-Walda agricultural drain and Portland Helwan drain (figure 1). Aquifers in the study area from top to bottom are (summarized after AbdelDaiem 1971; Research Institute for Groundwater RIGW 1978; Idris 2000; Sadek and Abd El-Samie 2001) the following.

\subsubsection{Quaternary aquifers}

A Holocene layer is composed of Nile silt, clay and sand with a thickness ranging between $10 \mathrm{~m}$ north of Helwan and $14 \mathrm{~m}$ in the south and vanishing near the eastern edges of the flood plain. The main sources of recharge are the direct downward infiltration from the cultivated land, irrigation canals and drains crossing the area as well as infiltration from others surface activities. The vertical hydraulic conductivity of the top clay cap varies between $5 \times 10^{-7}$ and $6 \times 10^{-8} \mathrm{~m} / \mathrm{s}$ and decrease substantially with depth (Shahin 1990).

A Pleistocene layers composed of silts, graded sands and gravels with total thickness ranging between $50 \mathrm{~m}$ north of Helwan and $80 \mathrm{~m}$ southward (Sadek and Abd El-Samie 2001). The Pleistocene aquifer in the Cairo area is of large areal extent, as it is connected hydraulically with the same aquifer, both in the Nile Valley in the southward direction and in the Delta in the northward direction. The real extent of the aquifer is bounded to the east by limestone escarpment. The main recharge source of groundwater is the water seepage from cultivated lands, irrigation canals and drains. In unsewered parts, the aquifer is recharged from sanitary trenches and pits as well as by the leakage from the deep aquifer system through major faults which bisect the study area. Groundwater discharge occurs as groundwater return flow to the Nile and by groundwater withdrawals. The general groundwater flow direction is in northward and westward directions towards the Nile.

\subsubsection{Tertiary aquifers}

Pliocene aquifer: It is mainly composed of fine to medium sands, clays, calcareous and argillaceous sediments. The main source of recharge to the Pliocene aquifer is upward leakage from Eocene fissured and cavernous limestone aquifer and the downward seepage of water from irrigation canals and drains.

Eocene aquifer: In the Helwan district, the fractured Eocene limestone has a wide distribution on the surface and in the subsurface. The Eocene sections within the area range between 400 and $800 \mathrm{~m}$ and overlay unconformably the Cretaceous Nubian sandstone aquifer (Idris 2000). The fissured and cavernous Eocene aquifer represents the main aquifer in the eastern parts of the study area. Secondary porosity is much more common in limestone aquifers than the primary porosity. The main sources of recharge to the carbonate aquifer are precipitation and the downward deep percolation from the Wadi-bed streams in the eastern sides of 


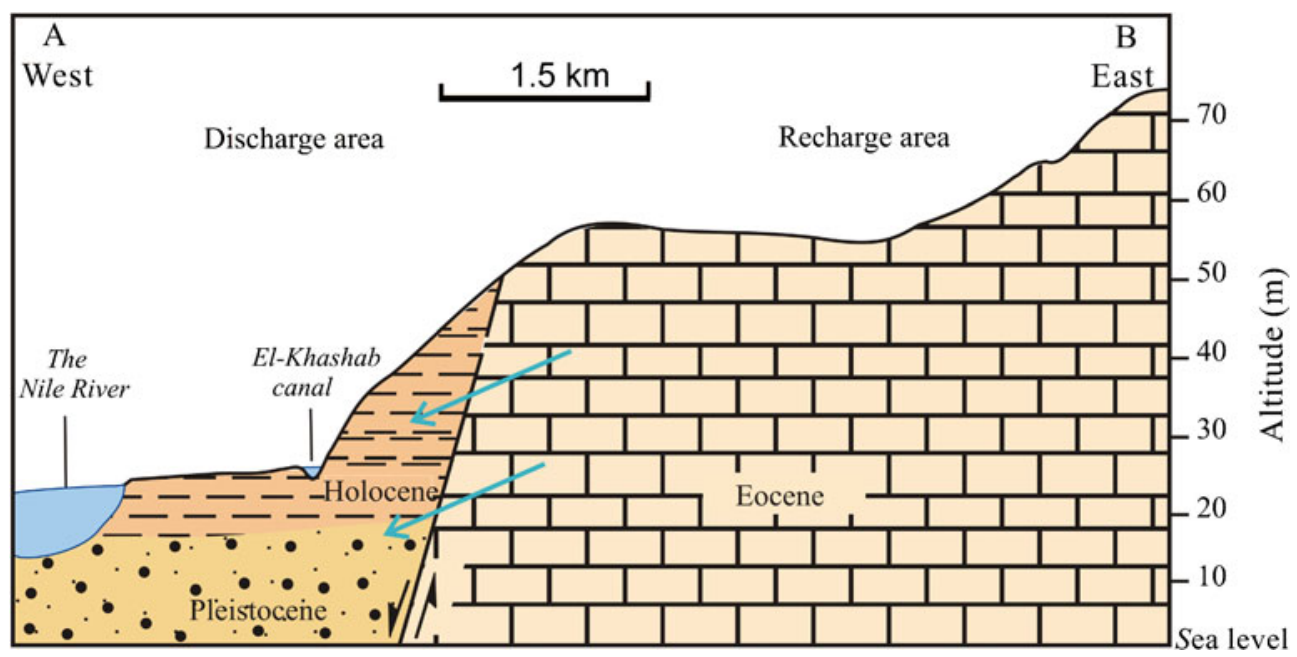

Figure 4. Schematic hydrogeological cross-section showing generalized direction of groundwater flow paths (modified from Abdu 1994).

the study area as well as upward leakage through fractures and faulting plains from the underlying Nubian sandstone aquifer due to the confining conditions in the Nubian sandstone aquifer. The Eocene fissured and cavernous limestone displays karstic features, through which the ground water egresses to several warm mineral springs within the Helwan area forming a good environment for chemical reactions. These springs are fed by upward water leakage from the underlying major Nubian sandstone aquifer through fissures, cracks, underground channels (caverns) and fault planes in the Eocene fractured and cavernous limestone. According to the Academy of Scientific Research and Technology ASRT and RIGW (1995), the main direction of the regional flow in the carbonate aquifer is generally driven by groundwater recharge due to deep percolation from the Wadi stream beds (figure 4). Therefore, the expected flow direction should be from the highlands towards the lowlands (i.e., towards the Nile).

The hydraulic conductivity of carbonate aquifer ranges between $6.4 \times 10^{-5}$ and $2.1 \times 10^{-3} \mathrm{~m} / \mathrm{s}$ (Wagdy et al 2008). The maximum reported value of the transmissivity (east of Qattara depression) is in the order of $3.2 \times 10^{-2} \mathrm{~m}^{2} / \mathrm{s}$, whereas the lowest value (nearby of Farafra oasis) is in the order of $2.3 \times 10^{-3} \mathrm{~m}^{2} / \mathrm{s}$. For Helwan area, the transmissivity value ranges from $4.6 \times 10^{-3}$ to $9.3 \times$ $10^{-3} \mathrm{~m}^{2} / \mathrm{s}$. The carbonate aquifer is fractured and cavernous, thus the secondary porosity plays an important role in the local groundwater flow and in

Table 2. Physico-chemical data of the springs, wells and surface water points in the study area.

\begin{tabular}{|c|c|c|c|c|c|c|c|c|c|}
\hline No. & Water point name & $\mathrm{pH}$ & $\begin{array}{c}\mathrm{T} \\
\left({ }^{\circ} \mathrm{C}\right)\end{array}$ & $\begin{array}{c}\mathrm{TH} \\
(\mathrm{mg} / \mathrm{L})\end{array}$ & $\begin{array}{c}\text { TDS } \\
(\mathrm{mg} / \mathrm{L})\end{array}$ & $\begin{array}{c}\mathrm{EC} \\
(\mu \mathrm{S} / \mathrm{cm})\end{array}$ & $\begin{array}{c}\mathrm{DO} \\
(\mathrm{mg} / \mathrm{L})\end{array}$ & SAR & SI calcite \\
\hline $1 \mathrm{G}$ & Stainless steel factory & 8.5 & 32 & 200 & 647 & 1134 & 2.7 & 3.97 & 1.20 \\
\hline $2 \mathrm{G}$ & Arab Abu-Saed & 7.9 & 27 & 966 & 2321 & 3677 & 2.2 & 2.23 & 1.10 \\
\hline $3 \mathrm{G}$ & Kafr El-Elw & 8.3 & 30 & 471 & 1199 & 2034 & 3.5 & 3.97 & 1.40 \\
\hline $4 \mathrm{G}$ & Helwan Spring & 8.0 & 28 & 1126 & 5240 & 9188 & 1.5 & 6.74 & 0.91 \\
\hline $5 \mathrm{G}$ & El-Set Khadra Spring & 7.9 & 32 & 1073 & 5342 & 9298 & 0.40 & 9.56 & 1.00 \\
\hline $6 \mathrm{G}$ & Ezbt El-Bharya Spring & 7.8 & 33 & 1068 & 5173 & 9075 & 1.0 & 8.81 & 0.85 \\
\hline $7 \mathrm{G}$ & Portland Helwan Quarry & 8.6 & 32 & 1439 & 13900 & 24260 & 1.8 & 31.6 & 1.60 \\
\hline $8 \mathrm{~S}$ & Nile River & 8.3 & 28 & 159 & 248 & 406 & 8.0 & 0.90 & 0.88 \\
\hline $9 \mathrm{~S}$ & El-Khashab Canal (El-Tebbin) & 8.1 & 30 & 311 & 385 & 652 & 0.1 & 0.54 & 1.25 \\
\hline $10 \mathrm{~S}$ & El-Khashab Canal (Kafr El-Elw) & 8.3 & 34 & 493 & 2397 & 4428 & 0.7 & 6.56 & 1.30 \\
\hline $11 \mathrm{~S}$ & El-Khashab Canal (Ezbt El-Walda) & 8.1 & 28 & 574 & 2090 & 3411 & 3.5 & 5.18 & 1.10 \\
\hline $12 \mathrm{~S}$ & Ezbt El-Walda Drain & 8.9 & 30 & 949 & 2104 & 3567 & 4.6 & 4.01 & 2.20 \\
\hline $13 \mathrm{~S}$ & Portland Helwan Drain & 8.5 & 30 & 111 & 223 & 383 & 2.1 & 0.82 & 0.64 \\
\hline
\end{tabular}

G: groundwater, S: surface water, TH: total hardness, TDS: total dissolved solids, EC: electrical conductivity, DO: dissolved oxygen, SAR: sodium adsorption ratio, SI: saturation index. 


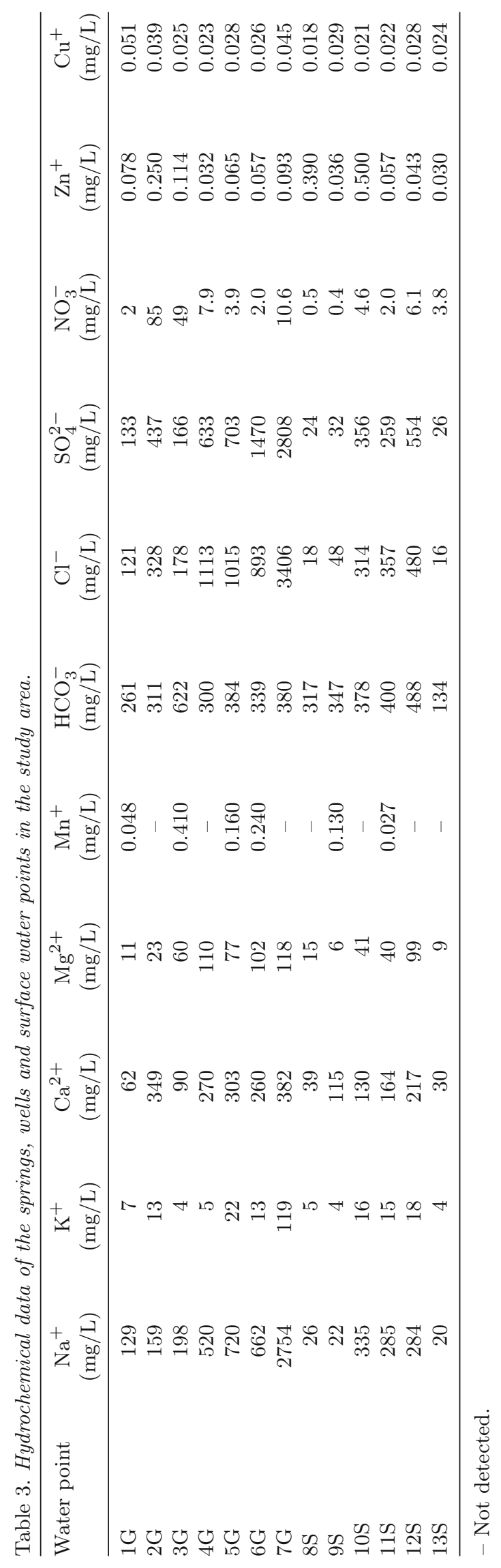

the recharge rates from Wady stream beds (Wagdy et al 2008). Excavation, construction and quarrying processes in different locations in Helwan area reveal the presence of shale and marl intercalation, faults, fracture zones and frequent karstic features such as cavities, voids and sinkholes.

\section{Methodology}

\subsection{Field and laboratory measurements}

The study is carried out with the help of two major components: input data from remote sensing, topographic sheets, geological maps, and data collected during the field work. The geological succession of the area (Awad and Abdel-Baki 1993) and field data have been used as a reference for the drawing of the geology and lineaments (faults) map as well as the main geomorphologic features of the study area. During field work, 13 water samples have been collected from Arab Abu-Saed, El-Tebbin, Kafr El-Elw, Ezbt El-Walda and Ezbt El-Bharya in June 2009. Seven of them are from the fractured carbonate aquifer (three water samples are from mineral springs and four water samples from wells) and six surface water samples from agriculture and industrial drains, canals and the Nile (figure 1). Names and locations of these water points are provided in table 2. On-site physicochemical parameters ( $\mathrm{pH}, \mathrm{T}$, total dissolved solids (TDS)), electrical conductivity (EC) and dissolved oxygen (DO) were measured (table 2). Field work also included the study of the geological and geomorphological features. In order to preserve the samples for cation and trace element measurements, samples were acidified using $\mathrm{HNO}_{3}$. The collected samples then were kept cool and dark until measurement. Laboratory work included chemical analysis of the collected water samples for cations, anions as well as for trace elements (table 3), followed by data analyses using e.g., AquaChem 3.7 and PHREEQC 2.17 for Windows. The concentrations of cations were measured using Atom Adsorption Spectrometry (Analytik Jena AAS NOvAA 400G), selected trace metals (Fe, Ni, Pb, Cd, Zn, $\mathrm{Cu}$ ) were determined by the application of graphite furnace AAS. For anion determination, ion chromatography (Dionex DX 120) has been used. These measurements were done at the geochemical laboratory of Berlin University of Technology. The saturation index (SI), which expresses the tendency of water towards precipitation or dissolution was calculated at formation temperature with respect to calcite as the main carbonate mineral using PHREEQC for Windows. A better measure of the sodium hazard for irrigation is the sodium adsorption ratio (SAR), which expresses reactions 
with the soil. For SAR calculations, units applied were meq/L (table 2) according to the US Salinity Laboratory Staff (USSL 1954) as follows:

$$
\mathrm{SAR}=\frac{\mathrm{Na}}{\sqrt{\frac{1}{2}(\mathrm{Ca}+\mathrm{Mg})}}
$$

Total Hardness $(\mathrm{TH})$ was calculated in $\mathrm{mg} / \mathrm{L}$ by the following equation (Todd 1980):

$$
\mathrm{TH}=2.497 \mathrm{Ca}^{2+}+4.115 \mathrm{Mg}^{2+} \text {. }
$$

\subsection{Land use maps}

Most of the study area is under particular anthropogenic activities for at least 55 years. To show the adverse effect of the temporal change in land use upon the quality of water resources in the study area, land use maps for year 2000 and 2010 were drawn with the help of GIS techniques and based on remotely sensed data, data from Dorsch Gruppe (2008) and field observations (figure 5).

These maps show that the study area has three main distinct zones. These zones are: (1) industrial areas, (2) residential along with some open areas, and (3) agricultural areas in the southern part of the study area which have changed dramatically from 2000 to 2010. This change has had negative impact on water resources in the study area including seepage of drainage waste water from industrial and residential areas (Shahin 1990; Abdel-Halim et al 2003). From these maps, it is clear that the major residential settlements are the city of Helwan, El-Tebbin, $15^{\text {th }}$ May town and other smaller residential settlements where industrial activities are highly concentrated in the southern half of the study area, particularly in the south of Helwan city.

The comparison of these two maps reveals significant differences in land use where urbanization is in a continuous increase during the time periods between 2000 and 2010. The agricultural areas nearly disappeared and were replaced by industrial and residential areas. Farmers tend to leave their lands without cultivation to sell it as construction sites for housing due to the high prices of land.

\section{Anthropogenic impact}

\subsection{Urban impact}

Urban and residential areas are generally confined to the banks of the Nile (figure 5). These maps show an expansion of urbanization with time by creating new communities. The old parts of Helwan area

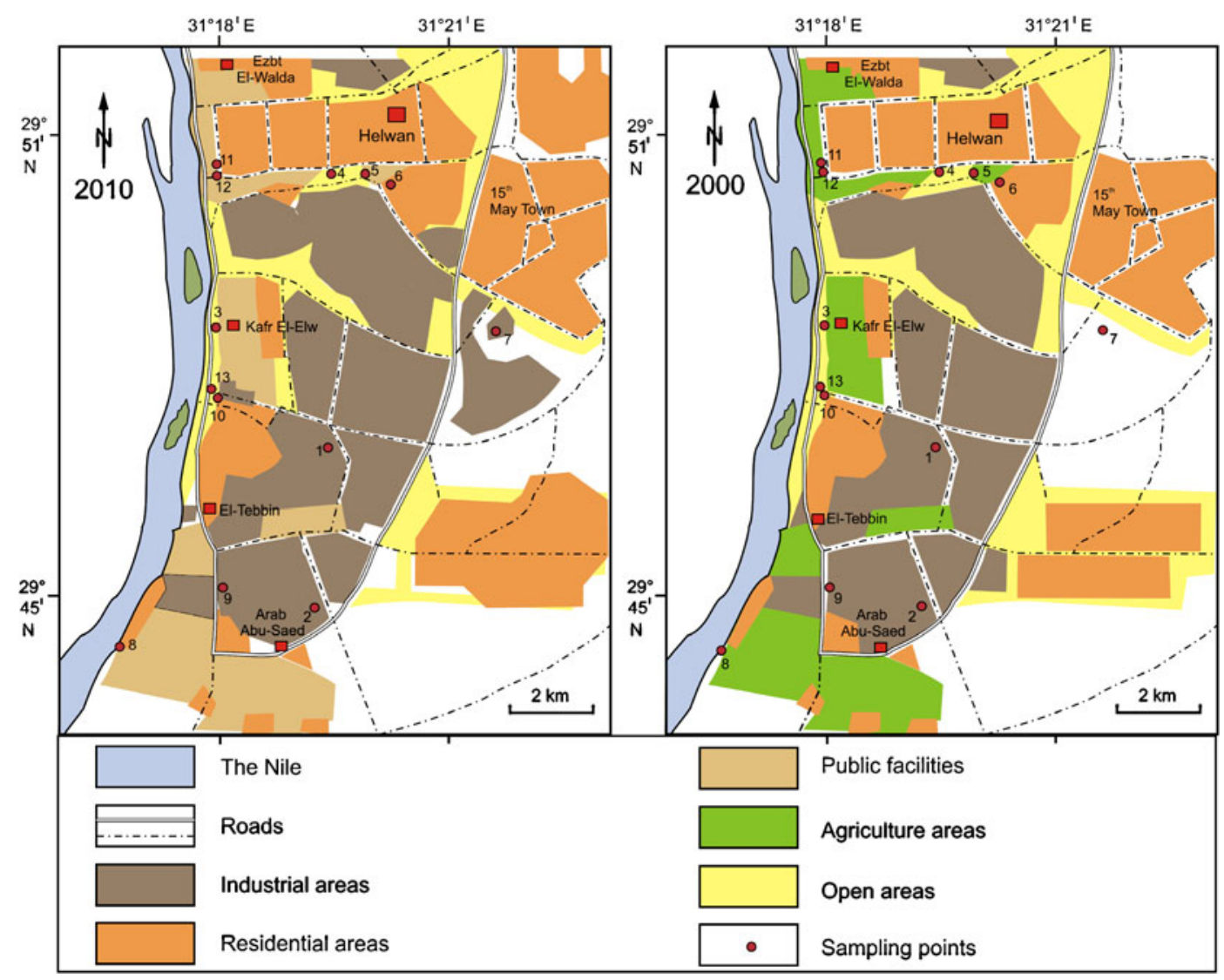

Figure 5. Land use maps in the study area in 2000 (right) and in 2010 (left) (modified from Dorsch Gruppe 2008). 
are served by a very old sewer system and some of the new settlements are served by septic tanks or latrines. Sewage leakage including sewage water from broken and leaking pipes might represent a great risk for water system in the study area. Also, in some areas, the sewage pumping vehicles used by residents of settlements are dumping their wastes into the southern part of El-Khashab canal. Furthermore, due to the lack of solid waste collection system, solid waste is dumped into waterways.

\subsection{Agricultural impact}

As shown from the land-use maps (figure 5), agricultural areas have decreased dramatically over time and only the southern part of the study area can be considered agricultural area (Arab AbuSaed and El Saaf town). A chemical of serious concern in groundwater quality degradation by agriculture is nitrate.

\subsection{Industrial impact}

In Helwan area, a number of the factories listed earlier are not connected to the sewerage network and discharge their untreated or partially treated effluent directly to the Nile or agricultural drains or to lagoons in the surrounding desert areas. Moreover, cement factories and other industrial activities are often the main sources of environmental pollution by either effluents or sulphur compounds (El Ghandour et al 1983a, 1983b; Abdel-Halim et al 2003).

\section{Results and discussion}

\subsection{Hydrochemical characteristics}

Results of the chemical analyses as well as SAR and SI for surface and groundwater samples in the study area are presented in tables 2, 3 and figures 6-9.

\subsubsection{Groundwater}

The observed temperatures at the different groundwater samples were within a range of $27^{\circ}$ and $34^{\circ} \mathrm{C}$, which is slightly higher than the recommendation limit of the World Health Organization (WHO 2008) and the Egyptian Higher Committee for Water (EHCW 2007). The examined ground water samples were slightly to moderately alkaline water where the $\mathrm{pH}$ value ranges between 7.8 and 8.6. Dissolved oxygen concentration is generally low in groundwater, the lowest value was detected in El-Set Khadra Spring $0.37 \mathrm{mg} / \mathrm{L}$, which might indicate an anaerobic condition. This agrees very well with the presence of dissolved manganese $(0.16 \mathrm{mg} / \mathrm{L})$.

Total dissolved solids: TDS measurements denote the various types of minerals present in water in the dissolved form. In natural waters, dissolved solids include mainly carbonates, bicarbonates, chloride, sulphate, phosphate, silica, calcium, magnesium, sodium and potassium. As expected, TDS and EC values of the groundwater samples exceed that of surface water samples which is attributed to waterrock interaction in the aquifer as well as the anthropogenic input. The lithological composition, leaching and dissolution of soil salts and chemical spills from wastewaters play an important role in the TDS values.

Water hardness: Water hardness is caused primarily by the presence of cations such as calcium, magnesium for total hardness and anions such as carbonate, bicarbonate for carbonate hardness. Hard water is not a health hazard, but it may be unsuitable for domestic use especially laundry. In the study area, TH varies between 200 to $1439 \mathrm{mg} / \mathrm{L}$ (figure 6) which reflects the higher contents of calcium and magnesium in water due to gypsum and anhydrite dissolution in the circulating waters. According to Sawyer and McCarty's (1967) classification, $77 \%$ of the samples fall under very hard class (>300 mg/L), 15\% fall under hard (150-300 mg/L) and the rest are moderately hard $(75-150 \mathrm{mg} / \mathrm{L})$.

Chloride and sulphate: Generally, greater mineralization of groundwater within the study area is associated with higher chloride and sulphate concentrations. The highest sulphate concentration was detected in spring water $(4 \mathrm{G}, 5 \mathrm{G}, 6 \mathrm{G})$ and Portland Helwan quarry 7G (632 to $2808 \mathrm{mg} / \mathrm{L}$ ), which might be due to gypsum and anhydrite dissolution in the circulating waters. Chloride showed highest concentration in Portland Helwan quarry $7 \mathrm{G}$ reflecting a potential input of sewage and waste water leakage from $15^{\text {th }}$ May town.

Nitrate: The nitrate concentrations in groundwater samples were between 0.4 and $85 \mathrm{mg} / \mathrm{L}$ (table 3 ). Since nitrogenous materials are rare in the geological record, nitrate in groundwater is usually due to anthropogenic activity. The highest nitrate values were recorded at Arab Abu-Saed Well 2G, close to the cultivated area and Helwan waste water treatment station. The well is located in an area where crops are irrigated mostly with sewage water and the sewage treatment station receives mixed sewage, industrial and domestic wastes in the influent as well as some 


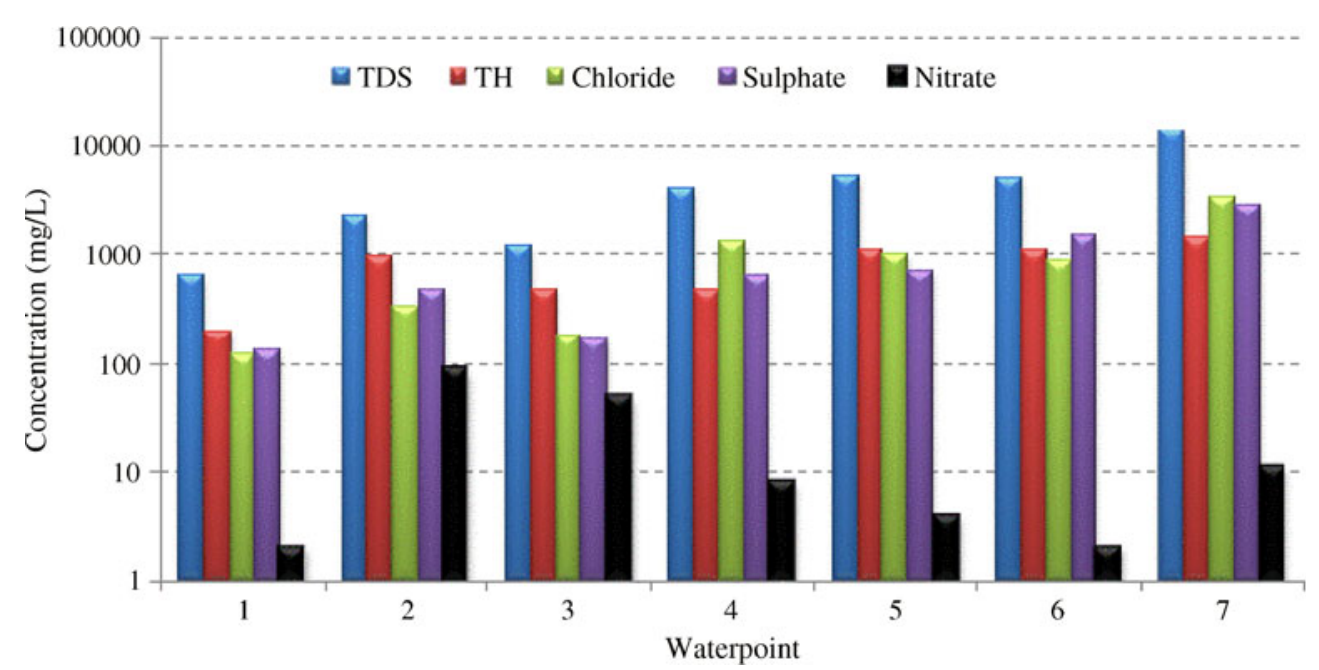

Figure 6. Variation of TDS, total hardness, chloride, sulphate and nitrate for groundwater samples.

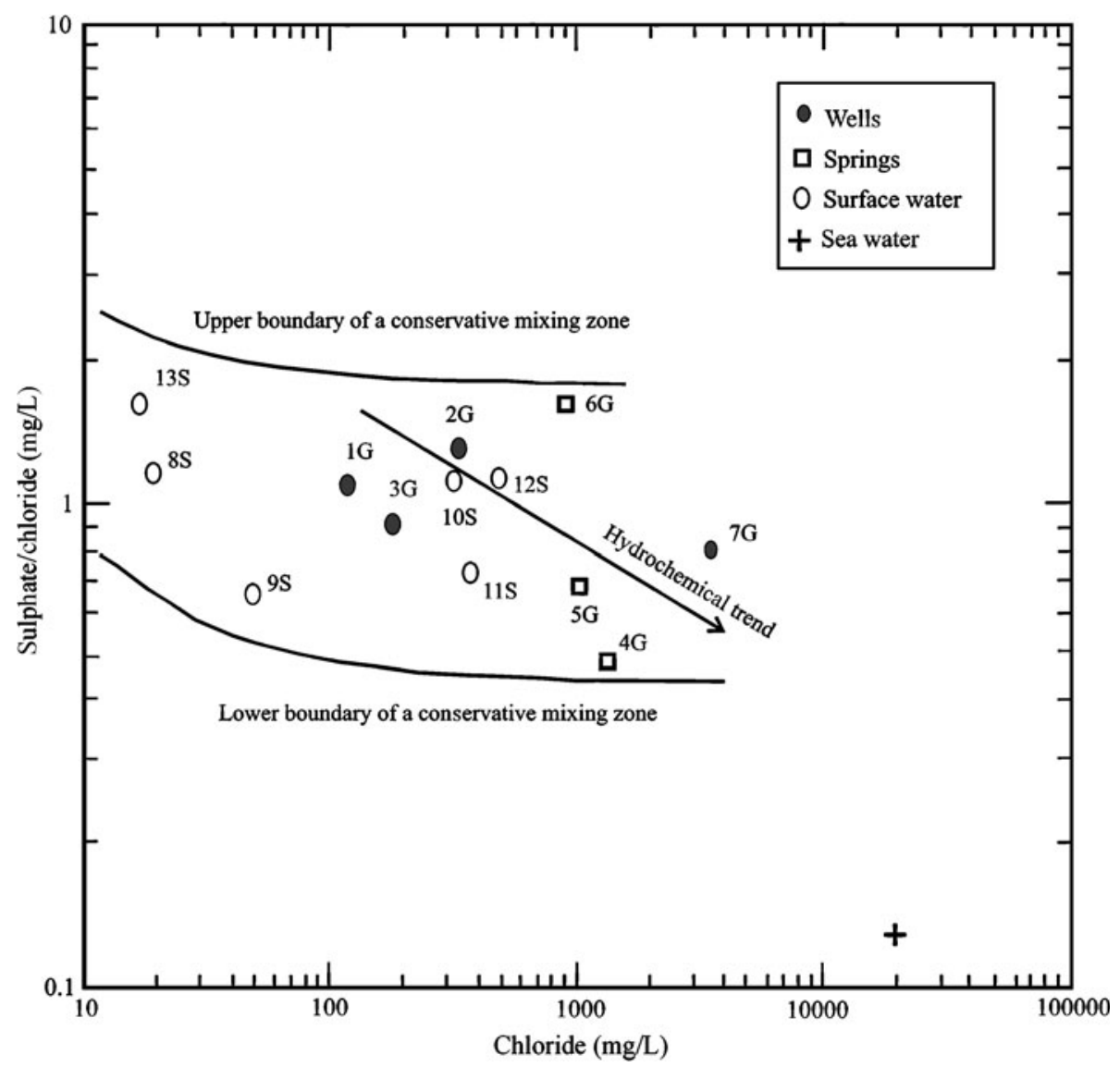

Figure 7. Molar ratio of $\mathrm{SO}_{4} / \mathrm{Cl}$ versus $\mathrm{Cl}$.

industrial ponds about $1 \mathrm{~km}$ away from the well. High nitrate concentrations were also detected at Kafr El-Elw Well 3G, which is enclosed by near standing houses in a densely populated area. Elevated concentrations of nitrate coincide quite well with low or undetectable concentrations of dissolved Fe and Mn.
Trace elements: Trace metals may present a serious threat to water quality due to their toxicity. They occur in dissolved form in water, as precipitates, or sorbed onto aquifer materials. Their concentrations in water depend on a number of chemical parameters, including $\mathrm{pH}$, ionic strength, alkalinity, and the presence of organic ligands, 


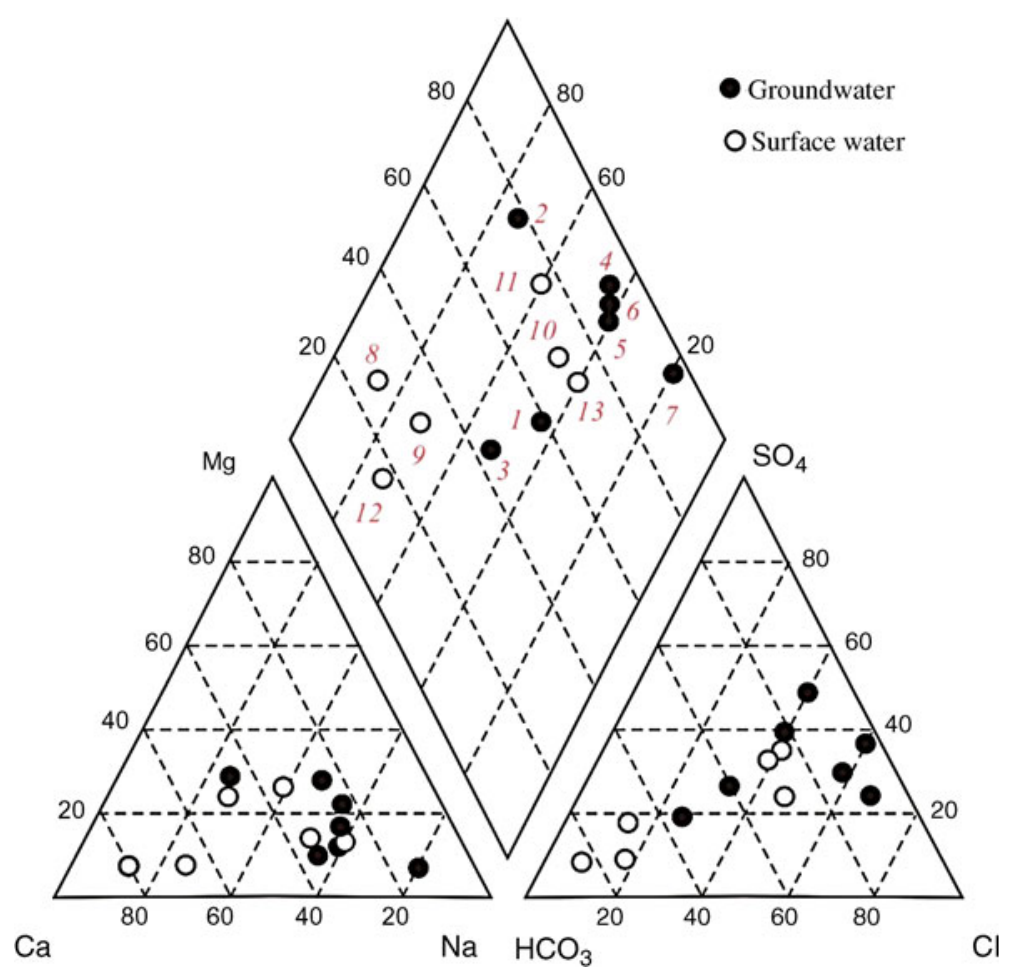

Figure 8. Piper diagram of the analysed water samples (numbers 1-13 indicate sampling points).

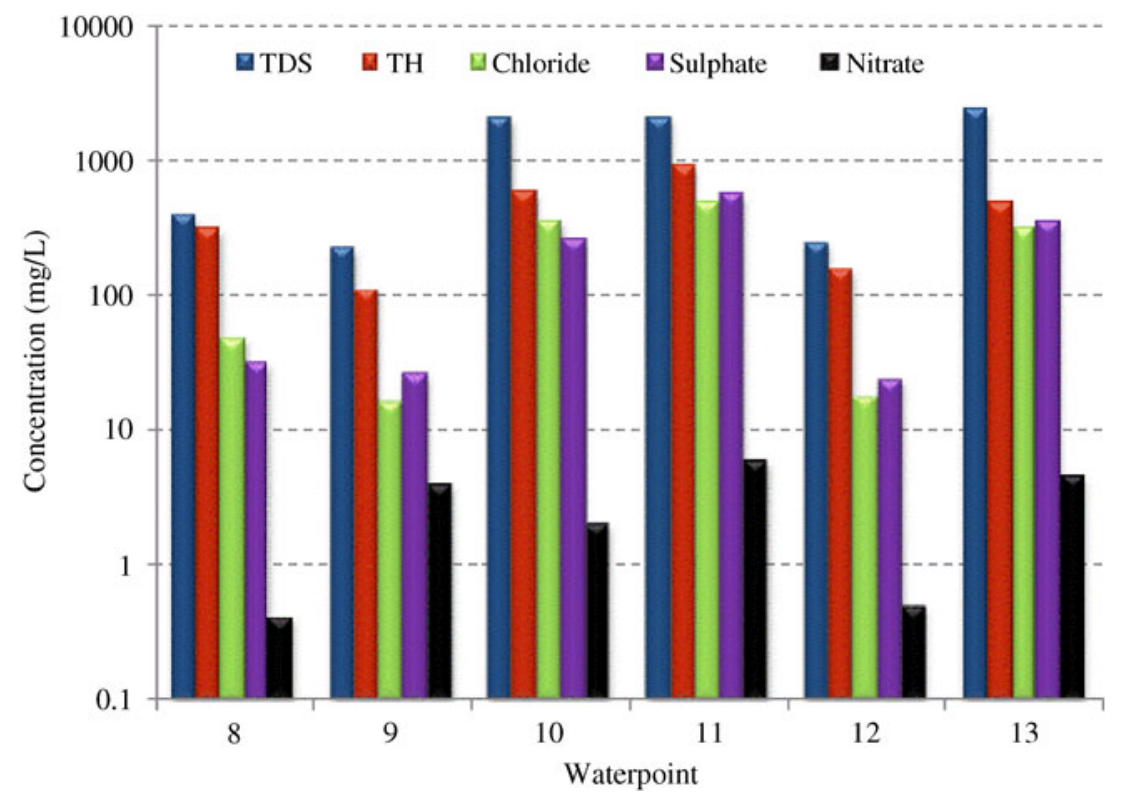

Figure 9. Variation of TDS, total hardness, chloride, sulphate and nitrate in surface water samples.

inorganic anions and other metal ions (Brown et al 2005). Trace metals above the detection limit in the study area include manganese, zinc and copper with maximum concentrations $0.41,0.50$ and $0.039 \mathrm{mg} / \mathrm{L}$, respectively. However, iron, nickel, lead, and cadmium were also analysed, but their concentrations were lower than the limits of determination $(0.005 \mathrm{mg} / \mathrm{L})$.
Ion ratios and chemical water type: Genesis of the groundwater in the study area has been defined by calculating the hydrochemical parameters $\mathrm{rNa} / \mathrm{rCl}, \mathrm{rCa} / \mathrm{rMg}$, and $\mathrm{rSO}_{4} / \mathrm{rCl}(\mathrm{meq} / \mathrm{L})$ and comparing these parameters with the standard values of normal sea water (table 4 ). These parameters can be used as a tool for detecting water contamination and water mixing from different sources. 
$\mathrm{rNa} / \mathrm{rCl}$ ratio indicates sources of salinity during groundwater flow (Cartwright and Weaver 2005). All groundwater samples showed that sodium ions exceed chloride ions except in Helwan Spring 4G, and Arab Abu-Saed Well 2G, the ratio was less than unity reflecting marine salt leaching. The high sodium concentration in groundwater indicates addition of sodium to water through the dissolution and ion exchange processes which withdraws $\mathrm{Ca}$ and gives $\mathrm{Na}$ to the solution. The presence of shale and marl intercalation (exchange sites), faults, fracture zones and frequent karstic features such as cavities, voids and sinkholes promote the suggested dissolution and ion exchange processes. The long residence time also favours cation exchange between $\mathrm{Ca}$ and $\mathrm{Na}$ on the exchange sites, so that the concentration of dissolved $\mathrm{Ca}$ is lower in groundwater samples.

$\mathrm{rCa} / \mathrm{rMg}$ ratios suggest the dissolution of calcite and dolomite present in the aquifer materials. Generally, values close to unity indicate dissolution of dolomite (Maya and Loucks 1995).

The $\mathrm{rCa} / \mathrm{rMg}$ ratios for $3 \mathrm{G}$ and $4 \mathrm{G}$ are very close to unity. However, the rest of the samples showed higher ratio which interpreted as being due to greater gypsum or calcite dissolution. Dissolution process is expected to be more common than ion exchange process due to the presence of faults, fracture zones and karstic nature of the aquifer media such as cavities, voids and sinkholes.

Ratios of $\mathrm{rSO}_{4} / \mathrm{rCl}$ and $\mathrm{rHCO}_{3} / \mathrm{rCl}$ reflect anion evolution during hydrogeochemical processes along flow paths (Han et al 2009). The $\mathrm{rSO}_{4} / \mathrm{rCl}$ ratio could be taken as a good indicator for detecting any excess of sulphate in groundwater associated with karst groundwater that has dissolved gypsum (Liang et al 2007) and leaching of terrestrial salts or oxidation of sulphides in the aquifers. The $\mathrm{SO}_{4}$ mixing represents either the oxidation of rock sulphur or the mixing of two different water masses and an oxidizing recharge. In case of water mixing, the $\mathrm{Cl}$ concentration varies. It is thus necessary to normalize the $\mathrm{SO}_{4}$ concentration with respect to $\mathrm{Cl}$ concentration to evidence the mixing process. The standard values of chloride and sulphate for sea water are 19400 and $2530 \mathrm{mg} / \mathrm{L}$, respectively. The simple mixing relationship between two defined water bodies can be well represented on a $\mathrm{Cl}$ vs. $\mathrm{SO}_{4} / \mathrm{Cl}$ graph (figure 7 ) (Fontes et al
1988). The two curves inside the figure represent the upper and lower boundaries of a conservative mixing zone enclosing the data. The ratio is less than unity except for Ezbt El-Bharya Spring, Arab Abu-Saed Well and Portland Helwan Drain. The higher ratio indicates a supplementary source of $\mathrm{SO}_{4}$ possibly due to the dissolution of gypsum on account of the long residence time. Samples gave higher values of $\mathrm{SO}_{4} / \mathrm{Cl}$ and $\mathrm{Ca} / \mathrm{Mg}$ ratios might indicate a long residence time of the groundwater in the aquifer, which enables the dissolution of gypsiferous fractions that are dispersed throughout the aquifer. The higher values of $\mathrm{SO}_{4} / \mathrm{Cl}$ ratio may be due to the dissolution processes throughout the aquifer and oxidation of rock sulphur meanwhile, a low contribution of organic soil could be expected.

The chemical water types in the study area were determined based on their chemical composition using the Piper trilinear diagram (Piper 1944), which is extensively used to understand the geochemical evolution of groundwater (figure 8). The two main water types found are $\mathrm{Na}-\mathrm{Cl}-\mathrm{SO}_{4}$ and $\mathrm{Na}-\mathrm{SO}_{4}-\mathrm{Cl}$, which reflect the intermediate and mature water phase. For spring water, the change of water type from $\mathrm{SO}_{4}$ to $\mathrm{Cl}$ with the flowpaths marks anion evolution during hydrogeochemical processes along flowpaths and depth circulation. Helwan Spring 4G is located near the end of the flowpaths (figure 1) and it might be the deeper and older spring where groundwater has great residence time in the study area.

\subsubsection{Surface water}

The surface water temperature varies between $28^{\circ} \mathrm{C}$ and $34^{\circ} \mathrm{C}$, which is in the same range for groundwater. The chemical characters of surface water (represented by the Nile, El-Khashab Canal, Ezbt El-Walda and Portland Helwan drains) revealed that the TDS values range from fresh $(<1000 \mathrm{mg} / \mathrm{L})$ to brackish $(<2000 \mathrm{mg} / \mathrm{L})$ (figure 9 ). Generally, surface water samples show low TDS values as well as low concentration of major anions and cations relative to groundwater. The TH values vary between $111 \mathrm{mg} / \mathrm{L}$ in Portland Helwan Drain and $574 \mathrm{mg} / \mathrm{L}$ in El-Khashab Canal at Ezbt El-Walda. Accordingly, all samples fall

Table 4. Calculated ion ratios of analysed water samples in Helwan area compared to equivalent standard of sea water.

\begin{tabular}{|c|c|c|c|c|c|c|c|c|c|c|c|c|c|c|}
\hline \multirow{2}{*}{$\begin{array}{l}\text { Ion } \\
\text { ratio }\end{array}$} & \multirow{2}{*}{$\begin{array}{c}\text { Sea } \\
\text { water }\end{array}$} & \multicolumn{13}{|c|}{ Water points } \\
\hline & & $1 \mathrm{G}$ & $2 \mathrm{G}$ & $3 \mathrm{G}$ & $4 \mathrm{G}$ & $5 \mathrm{G}$ & $6 \mathrm{G}$ & $7 \mathrm{G}$ & $8 \mathrm{~S}$ & $9 \mathrm{~S}$ & $10 \mathrm{~S}$ & $11 \mathrm{~S}$ & $12 \mathrm{~S}$ & $13 \mathrm{~S}$ \\
\hline $\mathrm{rNa} / \mathrm{rCl}$ & 0.854 & 1.64 & 0.76 & 1.79 & 0.32 & 1.09 & 1.14 & 1.25 & 2.19 & 0.71 & 1.65 & 1.23 & 0.91 & 1.94 \\
\hline $\mathrm{rCa} / \mathrm{rMg}$ & 0.194 & 3.42 & 9.20 & 0.91 & 1.07 & 2.39 & 1.55 & 1.96 & 1.58 & 11.63 & 1.92 & 2.49 & 1.33 & 2.02 \\
\hline $\mathrm{rSO}_{4} / \mathrm{rCl}$ & 0.100 & 0.81 & 1.00 & 0.72 & 0.36 & 0.51 & 1.21 & 0.61 & 0.97 & 0.50 & 0.84 & 0.53 & 0.85 & 1.23 \\
\hline
\end{tabular}


under fresh to very hard classes. DO concentration is generally higher in surface water than in groundwater except for the El-Khashab canal (upstream and middle part). Elevated concentrations of DO were observed for the downstream part of El-Khashab Canal $(0.1 \mathrm{mg} / \mathrm{L}$ upstream part at El-Tebbin, $0.67 \mathrm{mg} / \mathrm{L}$ middle part at Kafr El-Elw and $3.5 \mathrm{mg} / \mathrm{L}$ downstream part at Ezbt El-Walda). This variation in DO concentrations into the canal are likely due to the higher oxygen demand occasioned by the anaerobic degradation of organic matter in the upstream part (due to the raw sewage disposal into the canal as appeared from the presence of green algae cover in the canal water). The high content of sulphate and chloride at Ezbt El-Walda agricultural drain (10S) reflects the increased input from agricultural activities, domestic and industrial waste water discharge into the canals and drains. Also, high concentrations of chloride and sulphate were present in El-Khashab Canal at Kafr El-Elw (12S) and Ezbt El-Walda (9S) than those of the other surface water samples.

The lowest concentration of nitrate $(0.4 \mathrm{mg} / \mathrm{L})$ was found in the upstream part of El-Khashab Canal (9S), which might reflect the low input of nitrate into the canal where the input might be in the form of ammonium. Another explanation is the possibility of nitrate reduction due to the low DO concentration $(0.1 \mathrm{mg} / \mathrm{L})$ in the upstream part of the canal. Nitrate concentration increased towards the downstream part of the canal which could be due to oxidation of ammonium which agrees well with the DO and manganese behaviour in the canal water from upstream to downstream. The source of ammonium could be from raw sewage input into the upstream part of the canal.

The dominant water type for the Nile water is $\mathrm{Ca}-\mathrm{Mg}-\mathrm{HCO}_{3}$ and for El-Khashab Canal, it changes from $\mathrm{Ca}-\mathrm{HCO}_{3}$ at El-Tebbin (upstream part) to $\mathrm{Na}-\mathrm{Ca}-\mathrm{Cl}$ at Ezbt El-Walda towards downstream part. The addition of salts into the canal along the flow is reflecting by shift of the water type from $\mathrm{Ca}$ to $\mathrm{Na}$. This is confirmed by higher values of $\mathrm{Ca} / \mathrm{Mg}$ ratios due to inverse cation exchange.

\subsection{Water quality evaluation}

Water quality gives a clear picture about the usability of water for different purposes. In this study, surface and groundwater quality was studied based on different indices for drinking, irrigation and industrial purposes. The results of the chemical analysis were evaluated in accordance with the standards given by the WHO (2008), EHCW (2007), Ayers and Westcot (1985) and National Academy of Science (1972).

\subsubsection{Domestic purposes}

Evaluation of surface and groundwater quality for drinking purposes showed that sodium, calcium, potassium and total dissolved solid concentrations in most samples (except the Nile water) exceed the recommended limits of the WHO (2008) and EHCW (2007), accordingly they are not suitable for drinking and domestic uses.

The TDS of the groundwater in the study area ranged between $647 \mathrm{mg} / \mathrm{l}$ (for $14 \%$ of the samples collected), which is fit with the standards of WHO and EHCW, and more than $1000 \mathrm{mg} / \mathrm{l}$ (for $86 \%$ of the samples collected), which was higher than the recommended value of $1000 \mathrm{mg} / \mathrm{l}$.

For surface water, the results showed that the surface water in the study area is not suitable for drinking purposes, except Nile water. Most of the anion concentrations are above the maximum permissible levels. Chloride and sulphate $(2 \mathrm{G}, 6 \mathrm{G}, 7 \mathrm{G}$, $8 \mathrm{G}, 9 \mathrm{~S}, 10 \mathrm{~S}, 13 \mathrm{G}$ ) have been found in higher concentrations than the permissible limits for domestic uses. Nitrate is a very important element to be controlled in the drinking water due to its negative effects on the human health. Only groundwater samples $2 \mathrm{G}$ and $3 \mathrm{G}$ have nitrate values above the acceptable limits. Water hardness for $50 \%$ of the samples is below the maximum permissible levels for drinking water.

\subsubsection{Irrigation purposes}

The general criteria for judging the water suitability for irrigation purposes in this work are the total salt concentrations as measured by EC and SAR. According to Ayers and Westcot (1985) classification and based on SAR values, all water samples except $7 \mathrm{G}$ are below the irrigation standards and fall in the good and moderate quality class (table 5). Regarding EC values, more than $50 \%$ of the samples fall in the poor water class. Accordingly, most groundwater within the study area is unsuitable for irrigation without mixing with Nile water.

\subsubsection{Industrial purposes}

The study area is considered as one of the most important and old industrial fort in Egypt. Thus,

Table 5. Quality requirements for irrigation (Ayers and Westcot 1985).

\begin{tabular}{lccc}
\hline \multirow{2}{*}{$\begin{array}{l}\text { Potential } \\
\text { irrigation parameters }\end{array}$} & \multicolumn{3}{c}{ Degree of restriction on use } \\
\cline { 2 - 4 } & None & Slight-to-moderate & Severe \\
\hline EC $(\mu \mathrm{S} / \mathrm{cm})$ & 700 & $700-3000$ & 3000 \\
SAR & 3.0 & $3-9$ & 9 \\
\hline
\end{tabular}


evaluation of surface and groundwater quality for industrial purposes is very important. Water with high levels of chloride, sulphates and sodium or other ions will increase the water conductivity and may promote corrosion (Wilkes University 2002). To determine the corrosion potential in a recirculating water cooling systems through pipes, Langelier SI as indicator of water aggressivity or scale forming was calculated (table 2). Calcium carbonate is the most important ingredient in scale formed in cooling water lines (Kahler 1944). Control of Langelier SI in practices entails the adjustment of one or more of the following $\mathrm{pH}$, alkalinity and calcium hardness values (Zia et al 1999). Based on Langelier (1936), the calculated SI showed that the water is supersaturated with respect to calcite and has positive saturation index as being noncorrosive or scale-forming. According to the criteria of the National Academy of Science (1972), water in the study area (except the Nile) is not suitable for many industrial purposes without special treatment or mixing with the Nile water.

\section{Summary and conclusions}

The fractured Eocene aquifer in Helwan is highly vulnerable to pollution from the anthropogenic activities due to its surface outcrops and karst nature as reflected by the high mineralization value. Results showed that high concentrations of most ions in the groundwater probably result partially due to the background conditions (lithological composition and leaching and solubility processes) and contamination from surface activities. This is consistent with the significantly elevated values recorded at the site of Portland Helwan quarry compared to other groundwater samples (due to sewage waste water from the neighbourhood $15^{\text {th }}$ May town). Also, higher nitrate concentrations detected in Arab Abu-Saed and Kafr El-Elw wells are generally associated with infiltration of fertilizers and leakage from sewage from Helwan waste water treatment station. Groundwater in the area reflects the intermediate and mature water phase of metasomatism which marks anion evolution during hydrogeochemical processes along flowpaths and depth circulation. Surface water showed less TDS compared with groundwater, the low nitrate content of El-Khashab Canal and the drains might reflect the low input of nitrate while the concentration increased towards downstream of the canal which originated most likely from oxidation of ammonium. The study revealed that groundwater and surface water, except the Nile water reflect the saline water category; accordingly they do not suit domestic uses, meanwhile it could be used for agricultural and industrial purposes with some restrictions. Samples gave higher values of $\mathrm{SO}_{4} / \mathrm{Cl}$ and $\mathrm{Ca} / \mathrm{Mg}$ ratios might indicate a long residence time of the groundwater in the aquifer which enables the dissolution of small gypsiferous fractions that are dispersed throughout the aquifer. The presence of shale and marl intercalation within the fissured and cavernous limestone aquifer promotes the exchange reactions and dissolution processes which can potentially influence the hydrogeochemical characteristic of the groundwater.

As a conclusion, surface and groundwater in the study area were greatly affected from the anthropogenic activities, especially industrial activities, wastewater drains and leakage from sewage system; meanwhile, agricultural activities showed a low contribution.

\section{Acknowledgements}

The authors would like to thank the German Research Foundation DFG and the Egyptian Academy of Scientific Research and Technology ASRT for their financial support. They also wish to thank Mrs. Dunker from the drawing office, Mrs. Pieper and Mr. Yildiz from the geochemical laboratory of TU Berlin and Dr Karem Mubark from the geology department of South Valley University for their great help. The authors also extend their thanks to Prof. Grasby, Prof. Tallini, Prof. Petitta and Prof. Srinivas for their valuable comments in revising the manuscript.

\section{References}

Abdalla F A 2004 Contaminant transport in fractured chalk aquifer characterised by tracer techniques at Sigerslev, Denmark; PhD Thesis, Bonn University, Germany.

Abdel-Daiem A 1971 Hydrogeological studies of springs in the area east of Cairo; MSc Thesis, Ain Shams University, Cairo, Egypt.

Abdel-Halim A S, Metwally E and El-Dessouky M 2003 Environmental pollution study around a large industrial area near Cairo, Egypt; J. Radioanal. Nucl. Chem. 257 $123-124$.

Abdeltawab A 2008 Mokattam Plateau geology and stability; Japan-Egypt joint symposium new horizons in geotechnical and geoenvironmental engineering, Geotechnical Engineering Research laboratory, Tanta University, Tanta, Egypt, September 15-17.

Abdu I 1994 Geology and hydrogeology of Helwan area, Egypt; MSc Thesis, Menofia University, Egypt.

Aboushook M I and Sherif A 2000 Reinforcement of fissured large roof of the Egyptian broadcasting cavern in Mokattam Hill; Proceedings of ISRM Symposium Eurock 2001. Finland, Academy of Scientific Research and Technology (ASRT), pp. 401-408.

Akawy A and Zaky K 2008 Structural analysis of the tectonically inverted Kareim Basin, Eastern Desert, Egyp; Neues 
Jahrbuch für Geologie und Paläontologie, Abhandlungen 250 9-30.

Akawy A 2009 Structural elements and incremental strain history of the southwestern parts of exposed basement rocks: An example from Um Had area, central Eastern Desert, Egypt; Arabian J. Geosci. 2 285-300.

Awad M and Abdel-Baki A 1993 Water quality and environmental tritium for groundwater of the Quaternary aquifer in Mostorad station, northward Cairo, Egypt; Bull. Faculty of Science, Assiut University 22(2-F) 173-191.

Ayers R S and Westcot D W 1985 Water quality for agriculture; Food and Agriculture Organization, FAO Irrigation and Drainage, paper No. 29, Rev. 1, UN, Rome.

Bäumle R 2003 Geohydraulic characterisation of fractured rock flow regimes. Regional studies in granite (Lindau, Black Forest, Germany) and Dolomite (Tsumeb Aquifers, Northern Namibia); PhD Thesis, Department of Applied Geology, Karlsruhe, Germany.

Bäumle R, Hötzl H and Witthüser K 2000 Flow pattern and transport behaviour of granitic rock intersected by a highly permeable fault zone; In: Tracers and modelling in hydrogeology (ed.) Dassargues A (Wallingford, UK: IAHS Press), 262 283-288.

Bodin J, Delay F and de Marsily G 2003a Solute transport in a single fracture with negligible matrix permeability: 1. Fundamental mechanisms; J. Hydrogeol. 11 418-433.

Bodin J, Delay F and de Marsily G 2003b Solute transport in a single fracture with negligible matrix permeability: 2. Mathematical formalism; J. Hydrogeol. 11 434-454.

Brown S, Sprenger M, Maxemchuk A and Compton A 2005 Ecosystem function in alluvial tailings after biosolids and lime addition; J. Environ. Qual. 34 139-148.

Cartwright I and Weaver T R 2005 Hydrogeochemistry of the Goulburn Valley region of the Murray Basin, Australia: Implications for flow paths and resources vulnerability; Hydrogeol. J. 13 752-770.

Continental Oil Company (CONOCO) 1989 Geologic map of Egypt, scale 1; 500,000.

Dorsch Gruppe (Dorsch Consult Wasser und Umwelt $\mathrm{GmbH}) 2008$ Extension of Helwan wastewater treatment plant (internal report).

Egyptian Higher Committee for Water (EHCW) 2007 Egyptian standards for drinking water and domestic uses (in arabic).

Elawadi E, El-Qady G, Nigm A, Shaaban F and Ushijima K 2006 Integrated geophysical survey for site investigation at a new dwelling area, Egypt; J. Environ. Eng. Geophys. 4 249-259.

El Ghandour M F, Abdel Salam M S, Hindy K T and Kamel M M 1983a Studies on air pollution from construction plants in Helwan industrial area; 1. Total dust deposition over the area; Atmos. Environ. 17 303-309.

El Ghandour M F, Abdel Salam M S, Hindy K T and Kamel M M 1983b Studies on air pollution from construction plants in Helwan industrial area; 2. Water soluble and insoluble deposits; Atmos. Environ. 17 573-579.

Elminir H K, Areed F F and Elsayed T S 2005 Estimation of solar radiation components incident on Helwan site using neural networks; Solar Energy 79 270-279.

El Ramly I M 1969 Recent review of investigations on the thermal and mineral springs; XXIII International Geological Congress 19 201-213.

El-Sayed M H, Shawky H A and Abdel Mottaleb M S 2004 Geochemistry of water resources and pollution problems in Helwan area, Egypt; Bull. Inst. Desert Egypt 54(2) 259-289.

Farag A and Ismail M 1955 On structure of Wadi Hof area north-east of Helwan; Bull. Inst. Desert Egypt 1(5) 179-192.
Fayez M and Shahin R R 2007 Effects of industrial liquid wastes on dinitrogen fixation and microflora of soils and waters; J. Plant Nutr. Soil Sci. 150(4) 220-227.

Fontes J Ch, Louvat D, Michelot J L and Soreau S 1988 Isotopic content of aqueous sulphate, indicators of the origin of mineralization in crystalline rock groundwaters; In: Proceedings IAH symposium on the hydrogeology and safety of radioactive and industrial hazardous waste disposal, Doc. BRGM 160, OrleAans, pp. 325-341.

Idris M 2000 Geothermal evaluation for thermal fluids of Helwan Springs Egypt; Proceedings World Geothermal Congress, Kyushu-Tohoku, Japan, May 28-June 10, 2000.

Han D, Liang X, Jin M, Currell J M, Han Y and Song X 2009 Hydrogeochemical indicators of groundwater flow systems in the Yangwu River alluvial fan, Xinzhou Basin, Shanxi, China; Environ. Manag. 44 243-255.

Han D M 2007 Analysis of groundwater flow system and modelling of hydrogeochemical evolution in Xinzhou Basin, China; PhD Thesis, China University of Geosciences, China (in Chinese).

Kahler H I 1944 Once through and recirculation cooling water studies. Proceeding, Engineers Society Western Pcnna, pp. 39-62.

Langelier F 1936 The analytical control of anticorrosion water treatment; J. Am. Water Works Assoc. 28(10) 1500-1521.

Liang X, Han D M, Jin M G et al 2007 Mapping of karst water system round mountainous area and recharge to porous water in the Xinzhou Basin; Hydrogeol. Eng. Geol. 218(6) 28-32 (in Chinese).

Mahmoodabady H, Mirhosiny A, Hazery F and Morady F 2010 Investigation the effect of industrial development on groundwater pollution in arid zone (case study: Yazd province); The 1st IWA Malaysia Young Water Professionals Conference (IWAYP2010), 1-4 March 2010, Kuala Lumpur, ISBN 983-9805-86-4.

Maya A L and Loucks M D 1995 Solute and isotopic geochemistry and groundwater flow in the Central Wasatch Range, Utah; Hydrol. J. 172 31-59.

Moustafa A, Yehia A and Abdel Tawab S 1985 Structural setting in the area east of Cairo, Maadi and Helwan: Middle East Research Centre; Ain Shams University Science Research Series 5 40-64.

National Academy of Science 1972 Water Quality Criteria; Protection Agency, Washington DC, pp. 1-594.

Piper A M 1944 A graphic procedure in the geochemical interpretation of water analysis; Am. Geophys. Union Trans. 25 914-923.

Reed M H and Spycher N F 2000 User's Guide for CHILLER: A Program for computing water-rock reactions, boiling, mixing and other reaction processes in aqueous-mineralgas systems, and minplot guide (3rd edn), Department of Geological Sciences, University of Oregon, Eugene, OR, USA, 69p.

Research Institute for Groundwater (RIGW) 1978 Groundwater safe yield studies; Second technical report, ElKanater, Egypt.

Research Institute for Groundwater (RIGW) 1995 Regional prospective of the fissured carbonate aquifer system in Egypt; First technical report.

Sadek M A and Abd El-Samie S G 2001 Pollution vulnerability of the Quaternary aquifer near Cairo, Egypt, as indicated by isotopes and hydrochemistry; Hydrogeol. J. 9 273-281.

Said R 1954 Remarks on the geomorphology of the area east of Helwan; Bull. Soc. Geogr. Egypt 27 93-100.

Said R 1962 The geology of Egypt (Amesterdam: Elsevier) 348 p. 
Sawyer G N and McCarthy D L 1967 Chemistry of sanitary engineers; (2nd edn) McGraw Hill, New York, p. 518.

Shahin M A 1990 Impacts of urbanization of the Greater Cairo area on the groundwater in the underlying aquifer. Hydrological processes and water management in urban areas; Proceedings of the Duisberg Symposium, April 1990, IAHS Publ. 198.

Sultan S A, Mansour S A and Santos F A 2008 A hydrogeophysical investigation of the Ain Mousa area, near Cairo, Egypt; Bull. Eng. Geol. Environ. 67 111-117.

Taha A A, El-Mahmoudi A S and El-Haddad I M 2004 Pollution sources and related environmental impacts in the new communities southeast Nile Delta, Egypt; Emirates J. Eng. Res. 9(1) 35-49.

Tawfik K M 2008 A monitory field study at El Saaf-Helwan faba bean farms irrigated by industrial waste water and polluted water with sewage; J. Appl. Sci. Res. 4(5) 492-499.

Todd D K 1980 Ground water hydrology (2nd edn), John Wiley \& Sons, New York.
US Salinity Laboratory Staff USSL 1954 Diagnosis and improvement of saline and alkali soils; Agricultural Handbook 60, USDA, Washington, DC: US Government printing office.

Wagdy A, El Adway H and El-Gamal M 2008 Vegetation dynamics assisted hydrological analysis for Wady Degla; UNDP/GEF/Cairo University, Egypt.

Wilkes University Center of Environmental Quality, Geoenvironmental Science and Engineering Department 2002 Corrosion, saturation index, balanced water in drinking water systems - Source and cause of corrosion.

Witthüser K, Reichert B and Hötzl H 2003 Contaminant transport in fractured chalk: Laboratory and field experiments; Ground Water 41 806-815.

World Health Organization (WHO) 2008 Guidelines for drinking-water quality (3rd edn) incorporating the first and second Addenda, Volume 1, Geneva.

Zia M, Iqbal M, Nawaz H and Samin G 1999 Langelier calcium carbonate saturometry determination by table values; Int. J. Agri. Biol. 1 353-355. 